\title{
Future-proofing London
}

\author{
Sofie Pelsmakers
}

It is an undeniable fact that even a relatively minimal rise in global warming (around $0.8-1^{\circ} \mathrm{C}$ to date) has already had a discernible effect on our environment, causing sea level rises of up to 220mm (Allen et al, 2013; UKCP09, n.d). While the EU and UK governments have agreed that global warming must be limited to a maximum $2^{\circ} \mathrm{C}$ rise, global carbon dioxide $\left(\mathrm{CO}_{2}\right)$ emissions continue to rise at an alarming rate (Allen et al, 2013; UKCP09, n.d). Current records suggest that the world is heading towards a $2-6^{\circ} \mathrm{C}$ rise by 2100 , associated with a medium, or even high risk global warming scenario (Jennings \& Hulme, 2010). So what does this mean for our cities, and specifically for London?

In recent years, successive UK governments have made a commitment to ensuring that all new build dwellings are designed to 'zero carbon' by 2016, an objective to be rolled out across other building types by 2019 (DCLG, 2013). The government also envisages an upgrade of all existing buildings to zero, or close to 'zero carbon' by 2050 (DECC, 2011). This would suggest, if targets were met, that by 2062 the entire built environment in London will be virtually zero carbon.

Zero carbon buildings can only be achieved by building or upgrading existing structures to significantly increased building fabric energy efficiency standards, while also implementing on site renewable technologies and relying on a cleaner energy supply. In addition, it will also be necessary to make considerations for the projected impact of climate change on our existing and future designs, for it must be assumed that by 2062, our buildings and their occupants will be subject to different environmental conditions. Many UK buildings are designed with a lifespan of at least sixty years and $75 \%$ of existing UK housing is expected to still be in use in 2050 (SDC, 2006), so it is important that adaptation measures are considered now in order to withstand the climate changes predicted during that period.

\section{London's future predicted climate}

As evidenced by the facts below, climate change is already a reality in the UK:

How to cite this book chapter:

Pelsmakers, S. 2013. Future-proofing London. In: Bell, S and Paskins, J. (eds.) Imagining the Future City: London 2062. Pp. 73-83. London: Ubiquity Press. DOI: http://dx.doi.org/10.5334/bag.k 
- The UK has seen a $1^{\circ} \mathrm{C}$ temperature increase since 1970 (UKCP09, n.d).

- In the last 15 years London experienced the four hottest years on record, with 2006 exhibiting the highest temperatures in 350 years (UKCP09, n.d).

- When a prolonged heat wave hit the country in 2003, England and Wales suffered 2000 heatrelated deaths (an increase of 16\%) (UKCP09, n.d), with the greatest impact in London (Beizaee, 2013).

The discernible drop in temperature during the past few winters in the UK can be considered as further evidence of climate change. Global warming has caused record thawing of arctic sea ice, which in turn impacts on air and wind patterns worldwide. Instead of the milder Atlantic conditions usually experienced, atmospheric changes have caused a flow of cold Arctic weather to reach the UK (Ritter, 2013). It is likely that London will continue to see similarly cold and variable winters over the next few years, as a result of climate change induced ice melting (Huffington Post, 2013).

Long-term however, London's year round climate is predicted to rise by 2062, with warmer, drier summers, milder, wetter winters, and more extreme winds and rainfall (UKCP09, n.d). While increases in temperature will be incremental, the actual impact on the natural and built environment is expected to be significant.

It is likely that London will experience more extreme weather conditions, such as flooding, heat waves and droughts, the latter of which may increase the incidence of subsidence (Shaw et $\mathrm{al}, 2007$ ). Although the level of annual rainfall is not predicted to vary significantly, it is the distribution of rain which will become problematic, with more rain falling in winter (possibly up to a third more by 2062) and nearly equivalent decreases in summer. Temperatures in London in 2062 are also expected to rise by around $3-4^{\circ} \mathrm{C}$ in the summer and $2.5-3^{\circ} \mathrm{C}$ in winter (UKCP09, n.d). As such, $\mathrm{CO}_{2}$ emissions from space heating might decrease, but this is unlikely to cancel out the predicted increases in cooling energy during the summer.

Indeed, $\mathrm{CO}_{2}$ emissions from summer cooling are likely to increase significantly, exacerbating global warming, local air pollution and the Urban Heat Island effect in cities. Within these conditions, ill adapted buildings will struggle to provide the necessary thermal comfort, leading to heat-related deaths and illness, especially among the elderly and vulnerable. Prolonged temperatures over $35^{\circ} \mathrm{C}$ could also cause road surfaces to melt and other urban infrastructures to fail (UKCP09, n.d). Figure 1 illustrates this impact, where summer air temperatures in London might resemble Marseille's by 2080, but without the benefit of extra sun hours in winter.

Although these predicted weather conditions will be new to London, similar climatic conditions can be witnessed elsewhere around the world, and as such, provide us with existing strategies to prepare accordingly. Mediterranean cities can teach London how to adapt buildings to cope with increased summer temperatures, while cities in the Netherlands, a country with more than 50\% of its landmass below sea level, demonstrate how it might be possible to work with water, rather than against it to prevent flooding.

So what is the best way to combine mitigation strategies, while simultaneously building in adaptation measures to ensure our built environment continues to perform in a changing climate?

\section{Adapting our cities for the future}

The fact that we are operating in a changing climate can no longer be ignored. If London's buildings and infrastructure are not designed or adapted to cope, then temperature related health issues and flood damage will become significant problems (DEFRA, 2012). As set out below, it is critical 


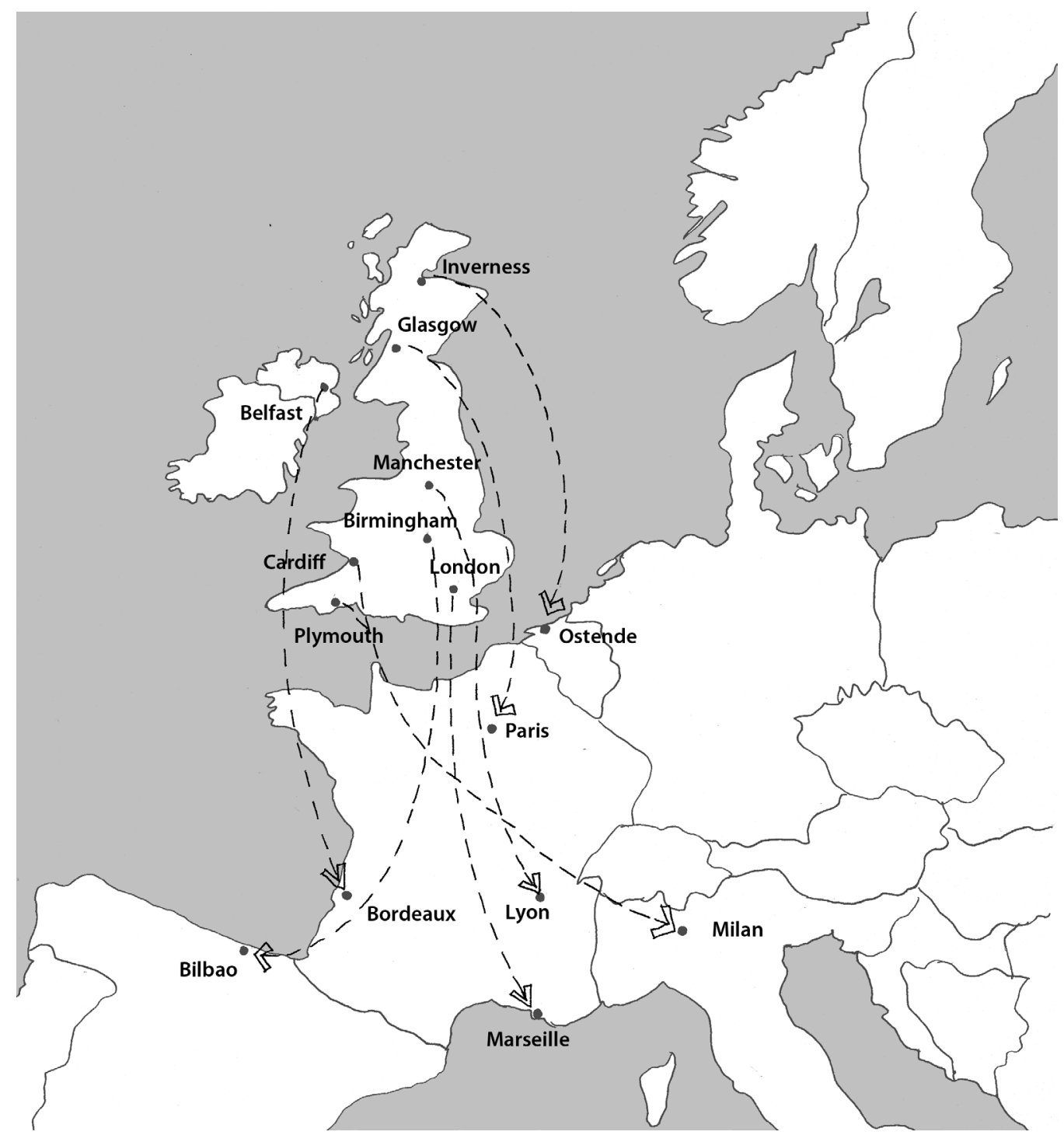

Figure 1: Predicted summer air temperatures in UK cities by 2080 (Pelsmakers, 2012).

that adaptation strategies are implemented early to prevent buildings from overheating and to safeguard occupants and property from floodwaters.

\section{Insulation and airtightness}

High fabric energy efficiency in the form of increased insulation and airtightness are key measures in the current climate for a sustainable built future, generally resulting in reduced space heat demand, increased thermal comfort and reduced fuel poverty. Despite the long-term prediction of increasingly mild winters, even super-insulated buildings will continue to require some winter space heating. In addition to helping to retain this heat, good insulation also buffers the internal environment from the external elements, whether cold or hot. So insulating in a warming 


\section{Most effective shading}

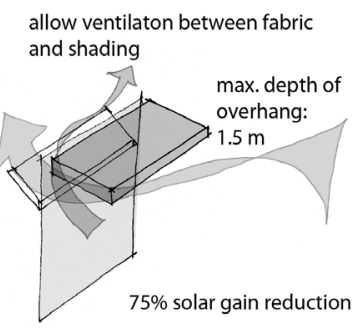

Horizontal solar shading south

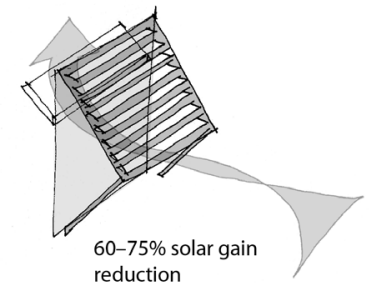

Awning
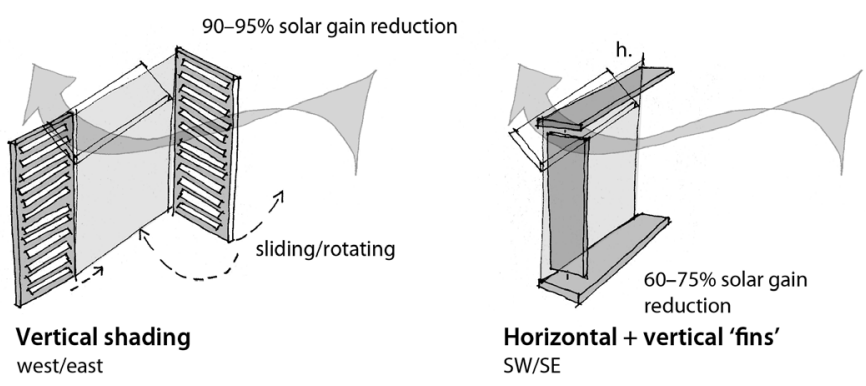

Horizontal + vertical 'fins' SW/SE

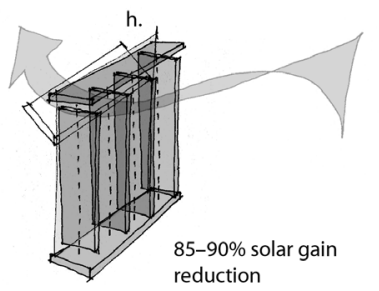

(Movable) vertical fins/louvres

Bottom three shading devices are suitable for all orientations if movable shading fins.

They are effective solar shading, but reduce daylighting and winter solar gain so use with care.

Design sliding/inward-opening windows, which do not impede natural ventilation. Design top inward-opening 'hopper' windows for night cooling (h.).

Figure 2: Effective solar shading devices dependant on orientation, while allowing for natural ventilation with inward opening windows. The illustrated top 'hopper' window is ideal for secure night cooling in thermally massive buildings (Pelsmakers, 2012).

climate generally still makes sense, and provides future-proofing according to short-term and long-term scenarios.

\section{Overheating prevention: building scale}

The prevention of overheating is important at both citywide and building levels, particularly as increased heat-related deaths occur even in relatively low external temperatures of around $19^{\circ} \mathrm{C}$ (Beizaee et al, 2013). However, it is not the increased temperatures per se that are dangerous, after all, there are many countries with far hotter climates. It is the irregularities in temperature, and the intensity and duration that people in the UK are unaccustomed to (Kalkstein, 2000; Vandentorren et al, 2006). Furthermore, UK buildings are often so ill adapted that indoor air temperatures can actually exceed those externally. This generates dangerous living conditions for those at risk, as internal temperatures above $35^{\circ} \mathrm{C}$ increase cardiovascular stress and the danger of respiratory diseases, especially in areas where local air pollution is high (Hacker et al, 2005).

The external temperature thresholds defined by the MetOffice for severe hot weather warnings are outlined as $32^{\circ} \mathrm{C}$ in the daytime and $18^{\circ} \mathrm{C}$ at night (Gething \& Puckett, 2013). Research has shown that even in mild summers recommended summer comfort temperatures and overheating thresholds $\left(26^{\circ} \mathrm{C}\right.$ in bedrooms; $28^{\circ} \mathrm{C}$ in living rooms, offices and schools (CIBSE 2005; 2006)) are already being exceeded by more than $1 \%$ of occupied houses studied in London and the South East, particularly in newer constructions (Beizaee et al, 2013). To prevent such risks, measures 
need to be incorporated into new building designs now, to ensure that internal temperatures can be maintained at a healthy, comfortable level for occupants, today and in the future.

Overheating is not caused by super-insulating buildings, but usually through a combination of high internal heat gains, a lack of summer solar shading, and ill designed or absent night ventilation in well insulated buildings. Incorporating external solar shading, combined with sliding or inward opening windows to allow good natural ventilation (as illustrated in Figure 2) are crucial adaptation strategies in both new build and refurbished building designs to prevent overheating.

In some cases however, the addition of external shading can cause significant structural difficulties when retrofitting, so planners may encourage less effective internal shading methods instead. Other good low energy practices, such as the specification of energy efficient appliances and the reduction of artificial lighting through good day-lighting design, can also help reduce unwanted internal summer heat gains. Additionally, as in Mediterranean traditions, taller floor to ceiling heights (greater than 2.7 metres) are useful for allowing the natural stratification of hot summer air to rise well above head height.

The presence of thermal mass in buildings can provide summer cooling of $3-5^{\circ} \mathrm{C}$, generating significant decreases in summer cooling energy demand (Hacker et al, 2008). This is only possible however, if secure night cooling is implemented to release built-up heat from the daytime, as failure to do so may cause overheating. When refurbishing, covering up solid walls with insulation can significantly decrease the available thermal mass of existing buildings and therefore, internal wall insulation upgrades need to be carefully considered to ensure continued summer thermal comfort in a warming climate.

If buildings are ill adapted to extreme temperatures, occupants may resort to the ad hoc installation of air conditioning units, generating significant increases in a building's typical operational energy use (Hacker et al, 2005). Air conditioning units also operate by 'dumping' excess heat outside the building, which only serves to augment external temperatures and exacerbate the Urban Heat Island effect (Tremeac et al, 2012; Vardoulakis \& Heaviside, 2012), and should therefore be avoided. Instead, future buildings must be designed to promote lower energy consumption through the use of natural ventilation and 'adaptive comfort' measures, such as the occupants' ability to adapt their clothing and manipulate windows and shutters for thermal comfort. While internal temperatures will never be as low as actively air conditioned buildings, designing a naturally managed building is about tempering the external environment within acceptable limits based on occupant control, which has been found to increase occupant satisfaction. It is the perceived difference between internal and external conditions that has been found to be more important than the actual temperatures achieved. In fact, air conditioned buildings have been associated with decreased occupant wellbeing (Steemers \& Manchanda, 2010).

\section{Overheating prevention: London scale}

Due to the Urban Heat Island effect, the impact of climate change is noticeably amplified within cities. The Urban Heat Island effect is generated by a combination of human activity, a lack of green spaces, plus the dark, thermally massive surfaces which constitute our cities. This results in an approximate rise in temperature of around $4-5^{\circ} \mathrm{C}$ in urban areas compared to the surrounding countryside.

At a city scale, heat build up can be prevented by introducing more green spaces throughout urban areas, particularly those that include 'water squares'. The larger the green space, the greater its tempering effect. This effect can be felt within spaces as small as $10 \mathrm{~m}$ diameter and on average, park areas tend to remain $2-3^{\circ} \mathrm{C}$ cooler than surrounding streets (Graves et al, 2001). Vegetation also provides some relief from the sun, reducing the elevated risk of skin cancer caused by prolonged exposure outdoors (DEFRA, 2012; Vardoulakis \& Heaviside, 2012). 

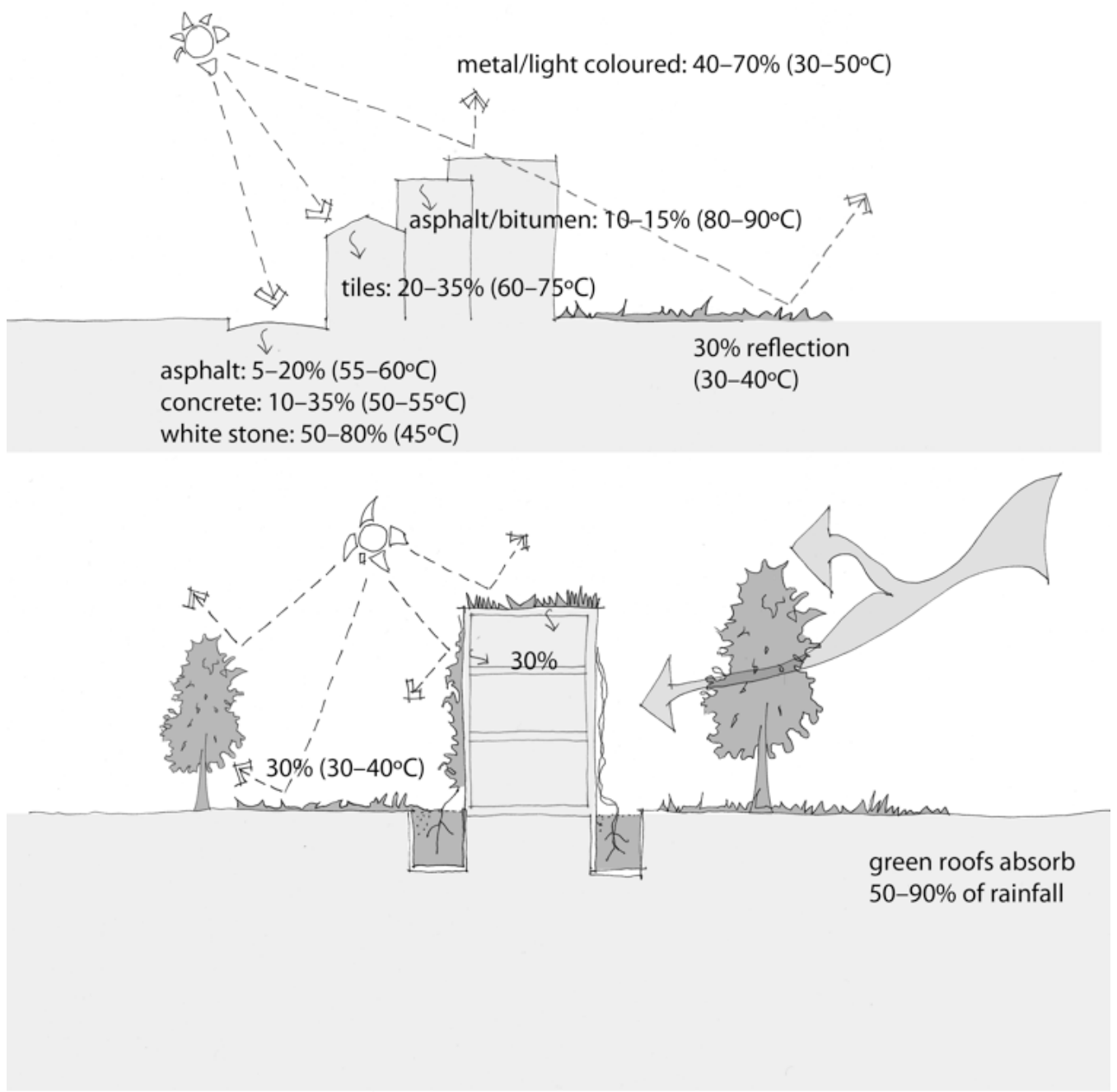

Figure 3: Typical solar reflection and surface temperatures of different materials, with a typical city's material built up at the top and a resilient city's built up below (Pelsmakers, 2012).

Implementing light, reflective external surfaces helps generate an 'urban cooling' effect by reducing the surface temperature of a building or infrastructure by around $10-20^{\circ} \mathrm{C}$ (Erell et al, 2011; Santamouris \& Asimakopoulos, 2001; Ward, 2004), as illustrated in Figure 3. An example of such adaptive measures can be seen in the specification of road surfaces in the UK, which have already been modified to ensure the materials can withstand greater temperatures and allow for increased drainage capacity following feedback from previous heat waves and flood events (DEFRA, 2012).

\section{Flood prevention: London scale}

There are around 2.5 million dwellings at risk of flooding in England and Wales (Carrington \& Salvidge, 2007; DCLG, n.d). In England, 11\% of dwellings are built in flood risk areas, most of 
which (around 850,000 properties) are in London. This means that up to $25 \%$ of homes in London are in danger, the majority of which at risk of river-flood damage, especially in the boroughs of Southwark, Hammersmith and Fulham, Wandsworth and Newham (Carrington \& Salvidge, 2007). Richmond Upon Thames holds the largest number of properties in the 'highest risk' category, but all London boroughs are at an increased risk of flash floods, due to the abundance of hard surfaces in the city combined with increased downpours and low capacity urban drainage systems (Carrington \& Salvidge, 2007).

Projected changes in climate are only likely to increase the risk of flooding, as global warming will continue to alter the intensity, duration and distribution of rainfall, resulting in more urban, and flash, flooding (ABI, n.d(a); n.d(b)). Furthermore, while risks are increasing, flood defence cutbacks threaten to make home insurance unaffordable for many (ABI, 2013; Carrington \& Salvidge, 2007).

Flooding is not only disruptive at an operational level, causing problems for the London Underground system and ground floor infrastructure, sewage and clean water supply of the capital, but it has health implications for the public (Vardoulakis \& Heaviside, 2012). Water as shallow as $15 \mathrm{~cm}$ deep can be threatening to those at risk, particularly the elderly or young, with mortality rates highest in flash floods (Vardoulakis \& Heaviside, 2012).

In order to future-proof our cities against these challenges, it is important to learn how to work with water, rather than against it. This includes undertaking flood risk assessments, allowing a minimum of $5 \%$ space for water storage on a site and the provision of efficient water flow channels (DCLG, 2006). Furthermore, green spaces, water squares and increased permeable surfaces can also help, for they not only reduce local summer air temperatures, but collect rainwater and aid water run off. This can reduce localised flash flood risk and acts as an amenity for city dwellers.

\section{Flood prevention: building scale}

To prevent the threatening consequences of flooding, such as loss of property, injury, disease and even death, it is vital that building adaptations are designed as an integral element of future citywide protections (DEFRA, 2012). At a building scale, considerations must be made for zoning, structural adaptations, and even the use of different typologies (illustrated in Figure 4), such as sacrificial ground floors, buildings on stilts, or floating buildings. Most existing structures can be 'wet-proofed', which means they are designed with possible future flooding in mind and result in only minimal damage to the property should this happen. This can be achieved through the use of water resistant materials for floors, walls and fixtures, and the siting of electrical controls, cables and appliances at greater than one metre height (DCLG, 2007).

\section{Climate change adaptation is a necessity, not a luxury}

Whatever the future holds, we cannot afford to be complacent - especially when considering these measures and many more can easily be incorporated into current design procedures as part of good new build and refurbishment practice.

Some measures can be implemented later, while others need to be effected immediately. For instance with new build, careful site planning and consideration for the orientation of a building must happen now, as with the specification of a well insulated building fabric and inward opening windows. However, intensive green or brown roofs could be implemented in the future, to reduce water run off and aid 'urban cooling' so long as the additional structural impact is taken into account and fixings are incorporated into the initial designs to make future adaptations easy and feasible. 


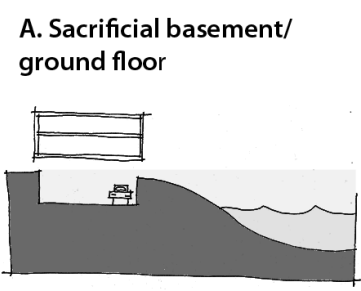

B. Building on stilts

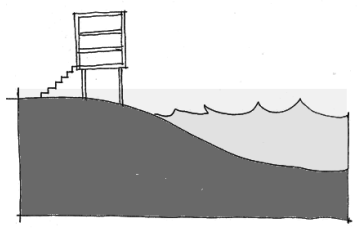

C. Floating buildings
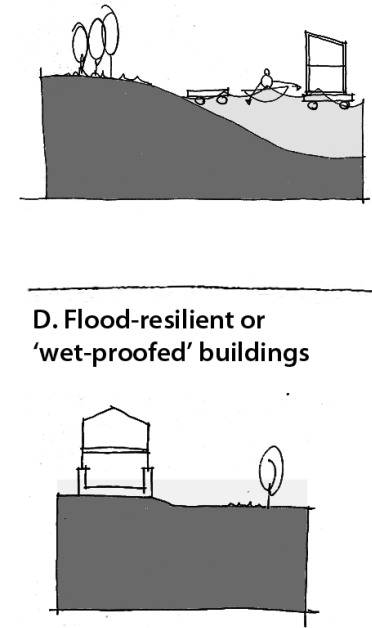

A raised ground floor with water retention in the basement (storage/car park) area, with residential at first floor. Suitable in low to medium flood probability zones.

This typology can lead to poor-quality street levels and security issues. Better to put workshop uses with less vulnerability on ground floor and vulnerable uses above to create active frontages. Move all equipment etc. above flood risk level.

Useful in a flood inundation area; but still needs protection from breakwaters to avoid debris damaging stilts structurally. Suitable in high flood probability zones. Difficult in an urban environment: issue with the undercroft and aerial walkways, usually lacking surveillance and ownership, leading to poor-quality street level and security issues. Lift or ramps required. Nothing can really grow under the stilts, to utilise as open space. Workshop/community infill space could be useful.

Ground floor rises with water levels up to around $5.5 \mathrm{~m}$. Usually built with EPS polystyrene slabs, with concrete screed over, to achieve floating ground floor base. Suitable in high flood probability zones. Good for areas where inundation can be controlled. Building on water avoids the need to reclaim land. Services to be encased in flexible pipework to allow vertical movement of buildings. Connection to a floating pier and mooring posts required. Most suited to smaller buildings. Usually low thermal mass buildings, which may lead to issues of summer overheating. Not many UK precedents, but more common in Netherlands.

'Wet-proofed' buildings are designed with possible
future flooding in mind and with minimal damage to
the property when this happens. This may be achieved
through the use of water-resistant materials for floors,
walls and fixtures and the siting of electrical controls,
cables and appliances at a higher than normal level. If
the lowest floor level is raised above the predicted
flood level, allow ramp access for disabled users.
Suitable in all flood probability zones.

Figure 4: Flood mitigation: building typologies that work with water (Pelsmakers, 2012).

Neglecting to future-proof our buildings will only result in a city ill adapted to the future needs of our society within a changing local and global environment. Buildings will fail to function effectively under extreme weather conditions leading to increased, wasteful energy use, and exacerbating the effects of global warming. At worst, the inability of our built environment to cater to the demands of its inhabitants might simply result in a stock of obsolete, unhealthy buildings unfit for purpose.

Designing for climate change adaptation on the other hand is guaranteed to increase building lifespan and help protect occupants from the detrimental effects of global warming, while also reducing the necessity for costly and carbon intensive interventions in years to come. Furthermore, there are other beneficial side effects to many adaptation measures, such as increased occupant satisfaction and wellbeing, and the support of London's declining wildlife through increased green spaces and trees (RSPB, 2013). 
The effects of climate change are an undeniable reality and to safeguard our cities from extensive damage we need to start designing for these changes right now. With sufficient foresight and planning, we can provide buildings which aid mitigation efforts and, when needed in the future, also support the ongoing adaptation of our cities for years to come.

\section{References}

ABI. 2013 (30 May). Insures continue to offer households access to insurance while negotiations with the Government continue. Available from: https://www.abi.org.uk/News/News-releases/2013/05/Insurers-continue-to-offer-householders-access-to-flood-insurance. [Accessed 17 August 2013]

ABI. n.d(a). Climate Adaptation Guidance on Insurance Issues for New Developments. Association of British Insurers. Available from: https://www.abi.org.uk/ /media/Files/Documents/ Publications/Public/Migrated/Flooding/Climate\%20adaption\%20guidance\%20on\%20insurance\%20issues\%20for\%20new\%20developments.ashx. [Accessed 17 August 2013]

ABI. n.d(b). Rising global temperatures will put the heat on insurance as flood costs rise new research from the ABI. Available from: https://www.abi.org.uk/News/News-releases/2009/11/ Rising-global-temperatures-will-put-the-heat-on-insurance-as-flood-costs-rise--new-research-from-the-ABI. [Accessed 17 August 2013]

Allen P., Blake L., Harper P., Hooker-Stroud A., James P. and Kellner T. 2013. Zero Carbon Britain. Machynlleth: Centre for Alternative Technology

Beizaee A., Lomas K.J, Firth, S.K. 2013. National survey of summertime temperatures and overheating risk in English homes. Building and Environment. 65:1-17.

Carrington D. and Salvidge R. 2013 (17 May) Flooding threatens one in four London properties. The Guardian. Available from: http://www.guardian.co.uk/environment/2013/may/17/ flooding-threat-london-property. [Accessed 17 August 2013]

CIBSE. 2005. TM36 Climate change and the indoor environment: impacts and adaptation. London: CIBSE

CIBSE. 2006. Guide A Environmental design. London: CIBSE

DCLG. 2006. Planning Policy Statement 25: Development and Flood Risk. London: The Stationery Office

DCLG. 2007. Improving the flood performance of new buildings. London: Department For Communities and Local Government

DCLG. 2013. Improving the energy efficiency of buildings and using planning to protect the environment. Available from: https://www.gov.uk/government/policies/improving-the-energyefficiency-of-buildings-and-using-planning-to-protect-the-environment. [Accessed 17 August 2013]

DCLG. n.d. Live tables on land use change statistics. Available from: http://www.communities. gov.uk/planningandbuilding/planningbuilding/planningstatistics/livetables/landusechange/. [Accessed 17 August 2013]

DECC. 2011. The Carbon Plan: Delivering our low carbon future. London: Department of Energy and Climate Change

DEFRA. 2012. UK climate change risk-assessment: government report. London: The Stationary Office

Erell E., Pearlmutter D. and Williamson T. 2011. Urban Microclimate: Designing the Spaces Between Buildings. London: Earthscan

Gething B. and Puckett K. 2013. Design for Climate Change. London: RIBA Publishing

Graves H., Watkins R., Westbury P. and Littlefair P. 2001. Cooling buildings in London: overcoming the heat island. London: BRE 
Hacker J.N., Belcher S.E. and Connell R.K. 2005. Beating the Heat: keeping UK buildings cool in a warming climate. UKCIP Briefing Report. Oxford: UKCIP

Hacker J., De Saulles T.P., Minson A.J. and Holmes M. 2008. Embodied and operational carbon emissions from housing: a case study on the effects of thermal mass and climate change. Energy and Buildings. 40: 375-384.

Huffington Post. 2013 (11 April). Climate Change 'Causing Colder British Winters' Says Met Office Chief Scientist. The Huffington Post, United Kingdom. Available from: http://www.huffingtonpost.co.uk/2013/04/11/climate-change-colder-winter-met-office-chief-scientist-_n_3059116. html. [Accessed 17 August 2013]

Jennings N. and Hulme M. 2010. UK newspaper (mis)representations of the potential for a collapse of the Thermohaline Circulation. Area. 42(4): 222-456.

Kalkstein L. 2000. Saving Lives during Extreme Summer Weather. British Medical Journal. 321: 650.

Pelsmakers S. 2012. The Environmental Design Pocketbook. London: RIBA Publishing

Ritter K. 2013 (29 March). Q\&A Europe's freezing Easter and global warming. Available from: http://phys.org/news/2013-03-qa-europe-easter-global.html. [Accessed 17 August 2013]

RSPB. 2013. State of Nature 2013. [Accessed 17 August 2013]; Available from: http://www.rspb. org.uk/stateofnature.

Santamouris M. and Asimakopoulos. 2001. Energy and Climate in the Urban Built Environment. London: Earthscan

SDC. 2006. Stock Take: Delivering Improvements in Existing Housing. London: Sustainable Development Commission

Shaw R., Colley M. and Connell R. 2007. Climate Change Adaptation by Design. Oldham: Town and Country Planning Association

Steemers K. and Manchanda S. 2010. Energy efficient design and occupant well-being: Case studies in the UK and India. Building and Environment. 45(2): 270-278.

Tremeac B., Bousquet P., de Munck C., Pigeon G., Masson V., Marchadier C., Merchat M., Poeuf P. and Meunier F. 2012. Influence of air conditioning management on heat island in Paris air street temperatures. Applied Energy. 95: 102-110.

UKCP09. n.d. UK Climate Projections. Available from: http://ukclimateprojections.defra.gov.uk/. [Accessed 17 August 2013]

Vandentorren S., Bretin P., Mandereau-Bruno L., Crosier A., Cochet C., Riberon J., Siberan I., Declercq B. and Ledrans M. 2006. August 2003 Heat wave in France: risk factors for death of elderly people living at home. European Journal of Public Health. 16(6): 583-591.

Vardoulakis S. and Heaviside C. 2012. Health Effects of Climate Change in the UK 2012. London: Health Protection Agency

Ward I. 2004. Energy and Environmental Issues for the Practising Architect. London: Thomas Telford 


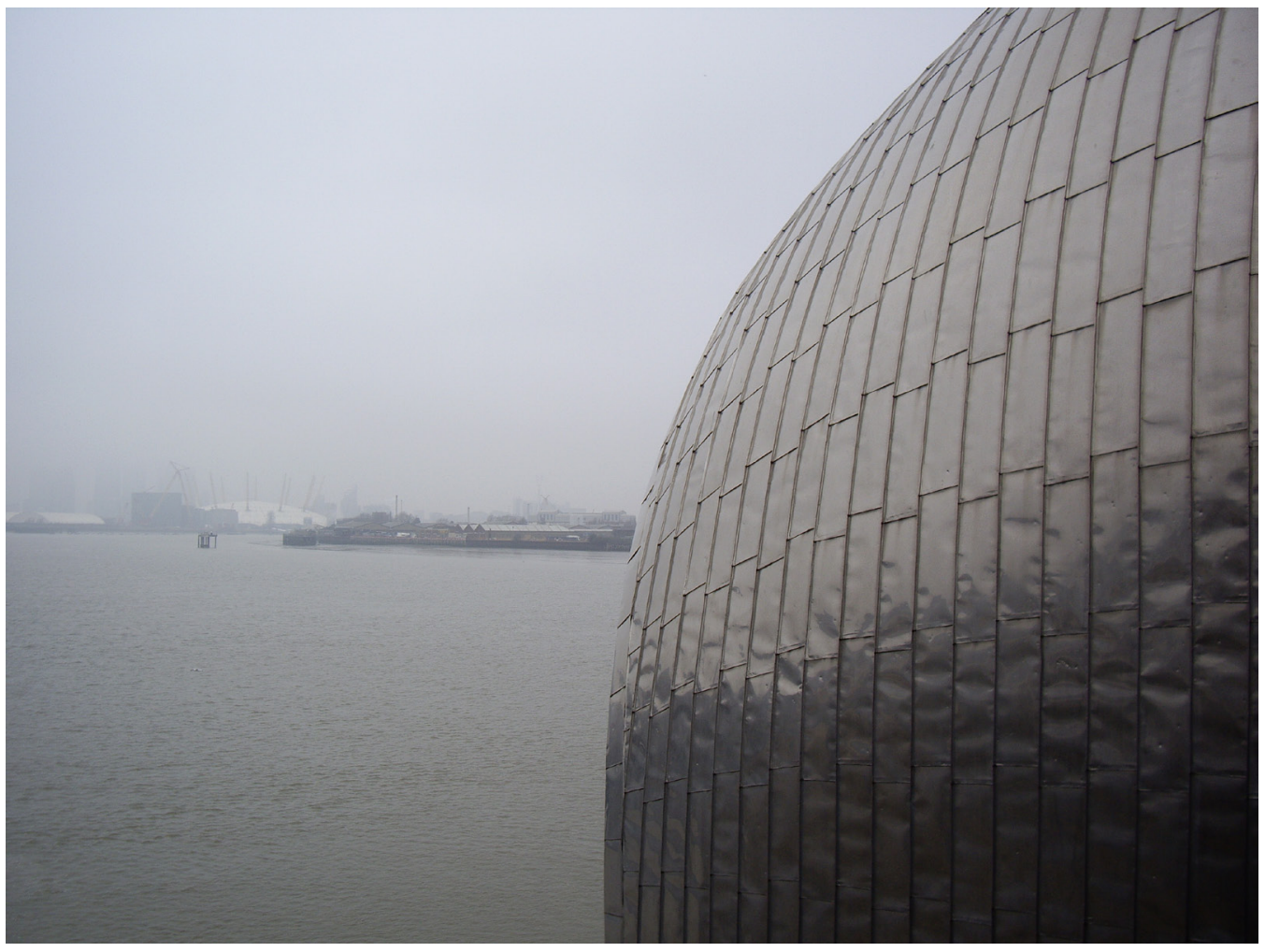

